\title{
LUT
}

University

\section{Institutionalization process of service innovation: Overcoming competing institutional logics in service ecosystems}

\author{
Jaakkola Elina, Aarikka-Stenroos Leena, Ritala Paavo
}

This is a Author's accepted manuscript (AAM) version of a publication

published by Springer, Cham

in Handbook of Service Science, Volume II

DOI: 10.1007/978-3-319-98512-1_22

Copyright of the original publication: ( ) Springer Nature Switzerland AG 2019

Please cite the publication as follows:

Jaakkola E., Aarikka-Stenroos L., Ritala P. (2019) Institutionalization Process of Service Innovation: Overcoming Competing Institutional Logics in Service Ecosystems. In: Maglio P., Kieliszewski C., Spohrer J., Lyons K., Patrício L., Sawatani Y. (eds) Handbook of Service Science, Volume II. Service Science: Research and Innovations in the Service Economy. Springer, Cham

This is a parallel published version of an original publication. This version can differ from the original published article. 


\title{
Institutionalization process of service innovation: Overcoming competing institutional logics in service ecosystems
}

\author{
Elina Jaakkola
}

Turku School of Economics, 20014 University of Turku, Finland

Tel. +358 2333 9222; Email: elina.jaakkola@utu.fi

\section{Leena Aarikka-Stenroos}

Tampere University of Technology, PO Box 527, 33101 Tampere, Finland

Tel. +358 50 3015476; Email: leena.aarikka-stenroos@tut.fi

\section{Paavo Ritala}

Lappeenranta University of Technology, PO Box 20, FI-53851 Lappeenranta, Finland

Tel. +358 40 8335852; Email: ritala@lut.fi

\begin{abstract}
Service science is concerned with the question of how systems can cocreate value in an optimal way. In essence, innovations aim at enabling better value co-creation; but at the same time, cause disruption and tensions in the service ecosystem by challenging prevailing practices. This chapter examines the development and diffusion of a broad scale heath care service innovation - the Electronic Prescription system (eRX) - as a process of institutionalization within a service ecosystem. This case represents an innovation process that attempts to solve a major societal challenge, rationalization of medication and reduction of medication errors and abuse. This change requires commitment and adaptation by diverse actors in multiple service systems affected by the eRX, but is nearly disabled by these actors' competing and even conflicting institutional logics. We examine how diverse stakeholders slowly move towards a convergent institutional logic as the innovation is gradually institutionalized in the broader service ecosystem, and discuss the major challenges along this process. This chapter highlights the dilemma of change in service ecosystems and highlights the role of institutions therein.
\end{abstract}

Keywords: service innovation; service systems, service ecosystems, institutionalization, institutional change, eHealth 


\section{Introduction}

Service science is concerned with the question of how systems can co-create value in an optimal way (Maglio and Spohrer 2008). In essence, innovations aim at enabling better value co-creation; but also cause disruption in the service ecosystem. In order to create value, the innovation has to resonate with the needs, practices, values, and institutional structures of the market and all of society, so that actors are able to make use of the new resource or in their value processes (Edvarsson and Tronvoll 2013). At the same time, however, an innovation typically causes change and disruption in the prevailing system, and new practices and structures may be needed before the value can be realized (Koskela-Huotari et al. 2016). For example, many innovations in the health care industry aim at reducing health care costs, but the prevailing institutions such as administrative, technical, or legislative infrastructure and systems do not support or adapt for the necessary change, or even protect the health care regime against radical innovations (Wallin and Fuglsang 2017). Reflecting such notions, Vargo et al. (2015) argue that institutionalization, i.e. the maintenance, disruption, and change of institutions, is a central process of innovation. Understanding how such process of institutionalization occurs, and what kind of obstacles it involves is therefore pivotal for advancing value co-creation through innovation in service ecosystems.

This chapter examines the development and diffusion of a broad scale heath care service innovation - the Electronic Prescription (eRX) - as a process of institutionalization within a health care service ecosystem. This case represents an innovation process that attempts to solve a major societal challenge, rationalization of medication and reduction of medication errors and abuse. This change requires commitment and adaptation by a diverse set of actors ranging from public organizations to business actors and citizens that are affected by the eRX, but is nearly disabled by these actors' competing or even conflicting institutional logics - the "deep-structural rules that coordinate and guide actor's perceptions and actions" (Geels 2012, p. 3). Existing research has shown that change taking place in markets often involves competing institutional logics and a battle for legitimacy and power (see e.g. Fuenfschilling and Truffer 2014). The institutionalization of a radical innovation therefore implies changes in the institutional logics within the service ecosystem as it involves the reshaping of institutions to better suit the new practices required by the innovation (cf. Geels and Schot 2007; Edvardsson et al. 2014). In this chapter, we highlight the challenges posed by competing institutional logics, and examine how the eRX service ecosystem slowly moves towards convergent institutional logics, i.e. similar or complementary interests and goals (Öberg and Shih 2014), as the innovation is gradually institutionalized.

Previous innovation research has highlighted that divergent logics between actors can be a source of innovation, as diverse actors can complement each other, but convergent logics among innovating actors is also needed to support the successful development and commercialization of innovation (Öberg and Shih 2014; Aarikka- 
Stenroos et al. 2017). However, despite highlighting the relevance of the stakeholders and diverse ecosystem actors surrounding the innovation, this research has predominantly focused on the technical development of the innovation (e.g., Rohrbeck et al. 2009), typically by actors involved in formal partnerships (e.g. Eisingerich et al. 2009). Less research has been conducted to address the whole process throughout which novel service processes evolve and become regimes in the interplay of versatile actors, i.e. how service innovation is institutionalized in the service ecosystem. This aspect is relevant especially in the case of radical innovations as "radically new technologies have a hard time to break through, because regulations, infrastructure, user practices, and maintenance networks are aligned to the existing technology" (Geels 2002, p. 1258).

This chapter contributes by highlighting the development and diffusion of major innovation as a process of institutionalization, analyzing in particular how competing institutional logics create tensions and barriers along this process in service ecosystems. As institutional logics shape individual and organizational actions (Thornton and Ocasio 2008), it is fruitful to examine how diverse actors with differing institutional logics achieve directions for joint actions, and the key obstacles therein. Development of convergent institutional logics has been identified a critical step for innovation to diffuse to markets, and gain legitimacy across relevant stakeholders (Wallin and Fuglsang 2017). This understanding is pivotal for gaining a broader view of service innovation that is interdisciplinary in nature, involving changes in technological, business, and human practices (Spohrer and Maglio 2008).

This chapter proceeds as follows. The next sections provide the conceptual basis of this study, discussing innovation as a process of institutionalization affected by institutional logics of the ecosystem actors. Next, we introduce the empirical case study of the development and diffusion process of the Electronic Prescription system in Finland. Subsequent sections analyze the empirical case as a process of institutionalization of innovation, and outline how competing institutional logics held by ecosystem actors challenge this process. Finally, we discuss the theoretical and practical implications of our research.

\section{Service ecosystem actors and institutionalization of innovation}

We start by discussing service ecosystems that serve as the context for innovating and comprise diverse actors who affect, and are affected by the institutionalization of innovations. Drawing from Service-Dominant (S-D) Logic, service ecosystems are defined as relatively self-contained, self-adjusting systems of resourceintegrating actors connected by shared institutional arrangements and mutual value creation through service exchange (Vargo and Lusch 2015). Value creation in service ecosystems is therefore affected by resources and contributions of a vast range of actors, such as customers and their social networks, businesses such as 
manufacturers and retailers, as well as actors that control or allocate public resources (Akaka et al. 2013). Health care service ecosystems comprise very divergent actors, including patients and their families and friends, healthcare professionals, hospitals, health support agencies, professional associations, health insurers, healthcare authorities, government agencies, and regulatory bodies (Frow et al. 2016; Litovuo et al. 2017; Verleye et al., 2017), as well as the technologies that the ecosystem applies (e.g., Capunzo et al. 2013).

Innovation can be understood as a process of exchanging and combining resources in new ways between actors in the service ecosystem (Perks et al. 2012). Innovation therefore induces chances in the practices of value co-creation among ecosystem actors (Vargo et al. 2015), and at the same time, necessitates that ecosystem actors are willing and able to engage in new practices (Edvarsson and Tronvoll 2013). As institutions, i.e. rules, norms, values and beliefs, and institutional arrangements, i.e. sets of interrelated institutions, provide the overall structure for how resources are integrated, innovation implies institutional change (Koskela-Huotari et al. 2016). The process of institutionalization, referring to the maintenance, disruption and change of institutions (Lawrence and Suddaby 2006), is therefore central for innovation (Vargo et al. 2015). One actor alone is a not able to maneuver such structures, but a dynamic and iterative process involving multiple stakeholders in the ecosystem that each have varying views on value is needed to maintain or change practices, and thereby ultimately institutionalize innovation (Vargo et al. 2015).

Resonating such notions, innovation research has emphasized that various actors and stakeholders such as distributors, consultants, suppliers, research institutes and universities, government agencies, and associations can impact the success of innovation by advancing or hindering development and commercialization (AarikkaStenroos et al. 2014; Rusanen et al., 2014) and therefore influence its institutionalization in the market/society (Geels 2002). For example, intermediaries are crucial in the case of consumer products because they make the product available to users (Woodside and Biemans 2005). Public organizations and educational institutions may support the diffusion by articulating positive visions of the use of the innovation in society (Troshani and Doolin 2007); and public and political authorities shape priorities of innovative actions (Geels 2002). Furthermore, expert opinion leaders, lead users, and user groups impact the formation or change of opinion, provide publicity, give advice and function as lead-teachers, demonstrate the new product, and explain its unique benefits over what is currently available and thus accelerate or block the adoption of the product (Woodside and Biemans 2005; Harrison and Waluszewski 2008; Aarikka-Stenroos et al. 2014).

The ecosystem actors' contributions to the innovation can be divided into three groups (Aarikka-Stenroos et al. 2014): on strategic level actors create markets for innovations, as regulators, investors, public organizations, and media as well as related firms together shape markets by breeding ecosystems; on more practical level users, media, and divergent organizations and communities build awareness and educate other actors and markets on the employment and benefits of the innovation; 
and finally all adopters and users facilitate and accelerate further adoption in markets by impacting attitudes and choices, and by creating the influence of critical mass.

\section{Institutional logics and innovation}

To understand institutionalization and institutional logics, we need to outline what we mean by institutions. The most typically adopted categorization follows three institutional pillars as defined by Scott (1995): 1) regulative institutions manifested by the existence of rules, laws, sanctions that constrain and regularize behavior; 2) normative institutions defining what is appropriate, i.e. what are the goals as well as the appropriate means of achieving them; and 3) cultural/cognitive institutions referring to culturally supported practices taken for granted. Together, institutions set the "rules for the game" in a given industry and affect resource integration by individual actors. Institutional settings (e.g. norms, rules, standards) of service systems affect individual actors' intensions, motivations and behaviors, but also the actions taken by actors influence existing institutions (Edvardsson et al. 2014). A broad range of actors engage in modifications and accommodations of institutional arrangements while acting and interacting to create value for themselves and for others, and at the same time their actions are enabled and constrained by institutional arrangements that are at least partially shared by the actors within a service ecosystem (Wieland et al. 2015).

Institutional logics, then, consist a particular system of socially constructed interpretations of how actors can operate under perceived institutional contexts. Institutional logics can be described as "deep-structural rules that coordinate and guide actor's perceptions and actions" (Geels 2012, p. 3) or "the socially constructed, historical patterns of material practices, assumptions, values, beliefs, and rules by which individuals produce and reproduce their material subsistence, organize time and space, and provide meaning to their social reality" (Thornton and Ocasio 1999, p. 804).

As discussed earlier, innovations are never only about technology, as their diffusion is a socially and institutionally embedded process. For instance, Geels (2002, p. 1257), notes that technological transitions "do not only involve changes in technology, but also changes in user practices, regulation, industrial networks, infrastructure, and symbolic meaning or culture". For radical innovations this often means that the institutional framework is poorly structured, including lack of coherent and shared economic and market structures, cognitive structures, user preferences and regulations (Geels and Schot 2007, p. 403). Furthermore, new technologies might be misaligned with the existing institutions, leading to the lack of legitimacy among focal institutional dimensions (Markard et al. 2016).

Therefore, the stronger the institutional structure around the innovation, the better the chances of its adoption - and vice versa. In this regard, it has been suggested 
that 'levels of structuration' of institutions can be viewed as the degree of institutionalization (Fuenfschilling and Truffer 2014). Furthermore, as the level of institutionalization grow, so does the commonly shared institutional logics (Thornton et al. 2012). In service ecosystems one of the core issues that enable their coordination is the shared institutional logics among the relevant ecosystem actors, including individuals, organizations, as well as policy-makers (see e.g. Vargo et al. 2015). This accentuates the need for creating convergent logics among actors affected by the innovation.

\section{Competing institutional logics as barriers to institutionalization}

In this paper we focus particularly on barriers for diffusion and adoption and the consequent institutionalization of innovation. Even though interest on innovation barriers has been growing, the barrier approach remains a much smaller and lessorganized research stream than the driver approach (Mohnen and Rosa 2002). Innovation barriers are issues that either prevent or hamper innovative activities: they can be "total barriers" that prevent innovative activities in firms or they can be understood as obstacles that can be overcome with effort (e.g., D'Este et al. 2012; Sandberg and Aarikka-Stenroos 2014). Barriers are largely relative and context dependent; what constitutes a barrier and the extent to which it hampers innovative activities depends on the firm and its characteristics (Sandberg and Aarikka-Stenroos 2014). Barriers can occur on systemic levels such as in the case of large technical systems that tend to be strongly path-dependent; in such situations there is a need to overcome prevailing standards and to compete against the established product and technologies (Markard and Truffer 2006). Some barriers are positioned in structures and concern routines, changing status-quo, and lack of market structure (D'Este et al. 2012). In other words, the change required in prevailing institutions and institutional arrangements in the service ecosystem represents an important source of innovation barriers.

In a particular organizational field - as the service ecosystem of eRX in our study - institutional logics provide the key organizing principles for the ecosystem (see Friedland and Alford 1991) but also a key source of imbalance (Verleye et al., 2017). As especially radical innovations require changes in a range of "rules and norms", and thereby practices by a number of industry players whose interests may not be harmonious with each other, tensions may emerge throughout the innovation institutionalization process (Geels and Schot 2007). These tensions can be viewed through the lenses of competing institutional logics (see e.g. Ruef and Scott 1998; Fuenfschilling and Truffer 2014). Research has also highlighted the importance of dominant logics and shifts from one logic to another (e.g., Thornton and Ocasio 2008). Competing logics might either co-exist over a longer period of time, raising "issue fields" where these logics are debated among actors such as industry professionals, associations, company representatives, and policy-makers (Zietsma et al. 
2017). However, these contradictions might be resolved via relying on collaboration between the actors possessing those competing logics (Reay and Hinings 2009), or those logics might be reconfigured over time into a new convergent institutional logic among actors (Fuenfschilling and Truffer 2014). Verleye et al. (2017) argue that in complex health care ecosystems, competing institutional logics such as 'business logic' and 'patient care logic' cannot be perfectly balanced, but value cocreation can be achieved by securing the needs, wants, and interests of each actor to a reasonable degree by advancing communication, accountability, engagement, and responsiveness by ecosystem actors.

The tensions related to competing institutional logics in service ecosystems may be viewed as barriers to the innovation process, but also as stimulants of development (Vaaland and Håkansson 2003). Conflicts and tensions may arise especially between heterogeneous actors who often operate according to different logics, such as in the case of complex public health care ecosystems (Verleye et al., 2017). According to Driessen and Hillebrand (2013), stakeholders related to innovating can be divided into "market stakeholders" (comprising customers, competitors, suppliers, and retailers) and "non-market stakeholders" (comprising regulators and special interest groups), and differing perspectives i.e. logics may result in tensions.

In sum, a prerequisite for successful innovation is that it becomes institutionalized. Therefore it becomes essential to understand what facilitates successful institutionalization, and what kind of tensions and competing institutional logics might arise that create barriers to institutionalization.

\section{Case study: Development and diffusion of the Electronic Prescription system in Finland}

This chapter reports an extensive, complex multi-actor case study investigating the development and diffusion of the Electronic Prescription in Finland. The case captures the full innovation process of the eRX system in Finland during 2001 to 2016; covering the process from early visioning to full scale diffusion, and the role of a range of diverse actors in institutionalizing the innovation within the service ecosystem. Main sources of data for the case study comprise interviews, public report and studies, research publications, and media materials (for information on study methodology, see Appendix 1). The case represents a relevant area of eHealth worldwide: different Electronic Prescription Systems have been tested or implemented in several European countries and in the United States, and digitalization of prescribing is a part of the national eHealth strategy in many European Union (EU) countries (Samadbeik et al. 2017).

The innovation in this case a new way of prescribing and dispensing medicine: an electronic prescription $(\mathrm{e} \mathrm{RX})$ is a digital prescription for pharmaceuticals that a physician writes up and signs electronically and enters in the national Prescription Centre where pharmacies and other health care professionals can access it, replacing 
a paper prescription handed to the patient (Ministry of Social Affairs and Health 2015). The innovation process involves developing the technical specifications for the IT system, and also new practices of prescribing and dispensing medicine.

The eRX represent a major shaping of institutions and institutional arrangements as it is an 'irreversible' intervention in the large, multifaceted service ecosystem comprising a network of hospitals, doctors, clinics, pharmacies, authorities, commercial executors (e.g., software vendors) and patients (Salmivalli 2008). For the eRX to become functional, there was a requirement of simultaneous change in legislation, professional practice, information system protocols as well as practices of citizens, i.e. patients. The main actors or the eRX therefore include various governmental (e.g. Ministry of Social Affairs and Health and Social Insurance Institution), public (e.g. health districts and centers), and private actors (e.g., pharmacies, system suppliers and software companies).

Next sections analyze more in detail the service ecosystem, the development and diffusion process of the eRX, and challenges in the institutionalization of the new system.

\section{Ecosystem actors shaping the institutionalization in the eRX case}

The Finnish health care system resembles those of other Nordic countries and the UK in the sense that it covers the whole population and its services are mainly produced by the public sector and financed through general taxation. A distinctive feature of the Finnish system is the National Health Insurance scheme, which partly reimburses medications prescribed by a doctor, private sector examinations and treatments performed or prescribed by a doctor or dentist (Häkkinen 2005; Salmivalli 2008). The Finnish system is exceptionally decentralized: local authorities around the country are responsible for organizing primary and specialist medical care for residents of the municipality (Häkkinen 2005). Public health care is supplemented by private health care actors, especially in the larger municipalities. Medicines may be sold to the public only by pharmacies and subsidiary pharmacies. There were 810 privately-owned pharmacies or subsidiary pharmacies in Finland in 2016 (Association of Finnish Pharmacies 2016).

The process of developing the eRX system in Finland involved diverse actors. The actors that mainly influenced the specification of the eRX system included The Social Insurance Institution (SII) and the Ministry of Social Affairs and Health (hereafter 'Ministry'). The Ministry was responsible for steering the national development of healthcare IT and prompted the development process in motion. Their role was to develop the strategy, prepare the legislation, and define the system architecture as well as the necessary data structures for the eRX. SII as the national insurance institution was designated as the technical producer and administrator of the system. There were also a range of municipal and governmental associations and institutes involved, with the task of coordinating particular phases of the project. 
The primary private actors involved included technology experts such as IT and software companies and system developers whose responsibility was to develop and deliver technology and software to health care service providers and pharmacies.

Actors representing the professions and user groups affected by the eRX system were health service provides, pharmacies, and patients. The health care units and pharmacies were assigned into the projects to develop and pilot the eRX system and later to develop guidelines for its deployment and integration into existing systems and service processes. Also various associations and interest groups were active along the innovation process, assessing the project and giving statements on the perceived benefits and problems of the planned system from the perspective of a particular interest group. Finally, the diffusion of eRX was dependent on the numerous pharmacies, health care units and doctors who were supposed to renew their systems and service processes to accommodate to the new prescribing system. Also individual patients affected the pace of the diffusion as they could, until 2016, refuse to take eRX (Ministry of Social Affairs and Health 2015).

The eRX case thus illustrates a very complex constellation of diverse actors consisting of versatile market and non-market stakeholders (Driessen and Hillebrand 2013) all of whom affect the institutionalization of the innovation throughout the innovation process. Together these stakeholders constitute a service ecosystem, representing different types of layers in this system: the primary user layer; professional and industry layer, technological layer, and finally regulative and political layer (Figure 1).

Please insert Figure 1 here

\section{The process of development and diffusion of the eRX}

The eRX innovation process advanced through four main phases (Figure 2) (see also Aarikka-Stenroos et al. 2017 for a more detailed case description). Initial goal setting for the eRX took place during 2001-2002, started by the Finnish Ministry of Social Affairs and Health, which anticipated eRX would bring far reaching benefits on the national level. The Ministry assigned the Social Insurance Institution (SII) and the National Agency for Medicines (NAM) to develop an initial plan for a new national concept that was published in 2001.

Please insert Figure 2 here

The first development and piloting phase for the eRX system took place between 2003 and 2006. The Ministry assigned four units of health care organizations and a few pharmacies in different regions to participate in developing and piloting the concept. Aside from the IT-firm conducting system development, project participants did not get any financial compensation for their input. The project was mainly 
advanced by influential individuals in health districts who were personally convinced by the Ministry's vision and wanted to bring their municipality to the forefront of eHealth development. The general opinion among health care professionals did not favor the development plans, demonstrating the divergence in the institutional logics at the time. As privately owned businesses, pharmacies feared the costs of investments the eRX system would require, and they perceived the traditional system of dispensing medicines as less complicated. Doctors resisted changing their daily practice and did not want to spend time on learning new IT-programs. Health centres in municipalities were concerned about their budgets as new systems would require investments in new it-infrastructure and training personnel. For pharmacies and health centres the anticipated benefits of eRX, such as reduced medication errors, seemed distant. Because of these challenges, the pilot project advanced very slowly: by the end of 2004 only two out of the four piloting health care units had implemented the eRX integrated into electronic patient record (Salmivalli 2008). The pilot was terminated in 2006.

The second development and piloting phase (2007-2011) was led by the SII. This time the development was spurred by a law issued by the Finnish government in 2007 that commanded eRX to be deployed nationally by 2011. The SII employed an IT system provider to construct the technical system, and later assigned the piloting and refinement of the developed system to two project teams, comprising health centres, pharmacies, and software companies. According to many informants, the sheer volume of participants made the development very complex. Each groups of actors viewed the development project through their particular institutional logics. For example, the SII sought to ensure that the system had a good fit their health information archive; municipalities preferred an eRX system that would fit with their current IT-infrastructures; software companies considered only the technological aspects; and physicians wanted to have an easy user interface. It became evident that a law making eRX compulsory was not enough to secure different actors' compliance on project level functions, but it was necessary to involve them more closely to the development and make sure that everyone's views were heard. This was done by organizing regular events and meetings with representatives of different actor groups. The first fully operating eRX service was finally launched in 2010.

Full scale dissemination and diffusion of the eRX took place between 20122015. The law obliged all health care units and pharmacies to adopt electronic prescribing by April 2014. The practical challenge was that each health center and pharmacy in Finland had to adapt or renew their IT-infrastructure and service practices to deploy the eRX system. Especially health centers struggled with this: they had insufficient competence in dealing with IT-suppliers and self-governed health districts resented a system that was imposed nationally. The dissemination process was facilitated by assigning actors closer to each user group to coordinate the deployment process; municipal hospital districts for health centers, and the Association of Finnish Pharmacies for pharmacies. These organizations helped service providers put the needed practices and procedures in place. Eventually, a broad-based 
convergence of institutional logics across actor groups was witnessed as the service ecosystem gradually begun to view the eRX as the norm instead of disruption, despite maintaining some differing views on its practical implementation. Today, all pharmacies and close to every health service organization have joined the eRX system (Ministry of Social Affairs and Health 2015). The main events and challenges in this process are summarized in Table 1.

Please insert Table 1 here

\section{Barriers for the institutionalization of the eRX}

As the story of the eRX (see Table 1) reveals, the institutionalization of the eRX was complicated by lack of converging logics and thus shared commitment to the goal and the process of pursuing it. Different actors in the eRX service ecosystem held divergent institutional logics that affected their perceptions of the usefulness of eRX. The interviewees noted that in the beginning of the project, different stakeholders shared the mutual understanding that developing the eRX was in principle a worthy cause. They recognized many benefits electronic prescribing could create on the national level, such as rationalization of medication and medication costs, bringing health care up-to-date, and increasing the productivity of health care generally. The system could increase efficiency in prescription handling, for example, reduce telephone prescription queries from pharmacies to physicians. Another perceived benefit was the potential for improving the patient quality of care as an integrated system would make it easier to detect overlapping medication and thereby reduce medication errors and adverse drug interactions.

However, these expected benefits of the eRX seemed too distant to motivate the stakeholders to change their practices. A major source of tensions between the stakeholders was that many of the costs would be borne by one group of stakeholders (e.g. public and private health care providers, pharmacies), while the benefits would be realized for other stakeholders (e.g. patients, the society at large). Thus, in this case there was a clash between market logics and public welfare logics. The organizations participating in the pilot phase did not receive any financial incentives for participation: rather, they were expected to allocate resources for the pilots. Throughout the project, there was also confusion about who should cover the costs of transitioning to eRX. Individual stakeholders such as pharmacies and health care providers did not really expect any financial savings from the system, but on the contrary, they assumed that eRX would create more costs in terms of extended need of IT personnel and the upgrading of existing systems. Furthermore, while the costs of the project were to be borne in the beginning of the project, the potential benefits would only realize in the long run: the generation of any actual benefits would require that a significant proportion of all prescriptions were electronic, and as long 
as two systems were in operations (one for the paper prescriptions and one for eRX), the full scale benefits could not be achieved. Instead, the costs of both systems were running from the beginning. In general, many of the stakeholders shared the stance that the transition from paper prescription to eRX did not provide any great benefits, so the strong motivation to push and facilitate institutionalization was absent.

Evidently the key barrier for the eRX institutionalization process was the divergence of logics held by public and private actors reflected in the different agendas, values, and beliefs; this brought on conflicting interests regarding the eRX. The main driver of the development work during the 2nd Pilot phase, the Social Insurance Institution, wanted the new system to support its other data archive systems; and the IT and system suppliers were only concerned with the technology aspect of the eRX. Pharmacies and health centers in turn considered the practical hassle and cost of changing their IT and even physical infrastructures, and training their staff to adapt to the new service and prescription handling practices. There were also more profound barriers in the beliefs held by different professional communities; for example, professional associations of doctors and pharmacists had a generally negative stance towards outsiders imposing changes in the current practices, and some influential individuals even saw the eRX as a potential step towards online trade of medicines, something that was deeply resented by pharmacies.

It was also apparent that the leading actors driving the innovation process in the emerging service ecosystem initially did very little to create a common ground and converge different actors' viewpoints and logics closer together. During the first phases of the process, the end-users' perspectives were not taken into account to any considerable extent. Consequently, in the piloting phase, the eRX was not very attractive for the key end-user adopters, i.e. physicians, although their acceptance was a critical factor in the early phases of the institutionalization: physicians could choose between paper and eRX format during a long transition period which meant that they were the main gatekeeper for the wider diffusion of the eRX. Physicians who did not perceive any significant advantage in using eRX would not easily choose the new format in their busy daily practice. A factor contributing to their reluctance was that the first software versions were rather cumbersome to use: tens of mouse clicks were required to log into the system and to write a prescription.

Using the eRX was at first inconvenient also for the patients, as in the piloting phase, the eRX could be collected only in certain pharmacies that often were far away from the health center where the prescription was written. Patients therefore preferred a traditional prescription that they could collect in their nearest pharmacy. In practice, these inconveniences on the level of daily practices of primary end-user adopters overruled the potential benefits that could be gained on the society level, over a long period of time. 


\section{Discussion and implications}

This case study illustrated a longitudinal process of a major health service innovation - the electronic prescription - that was developed and diffused in Finland during a period of almost 15 years. The case study highlights in two key points: First, the eRX innovation process required involvement and adaptation by diverse actors in multiple service systems, but was significantly delayed and nearly disabled by these actors' competing institutional logics that prevented them from committing to the project and hence adopting new practices related to prescribing and dispensing medicines. The innovation process was initiated and led by public actors that, due to their own institutional logics, sought long-term, macro level benefits such as rationalization of health care and keeping Finland at the forefront of eHealth. On the other hand, the actors whose resources were needed to make the change happen followed different institutional logics and were therefore more concerned with more micro-level, proximate goals such as technology development (IT-service providers), business logics (pharmacies), professional service practices (doctors), resourcing and cost control (municipalities), and convenience (patients).

These findings are in line with earlier notions that that diverging logics are a key source of tensions disrupting value co-creation in health care ecosystems (Verleye et al., 2017) and largely hinder collaboration for innovation by inducing competing or conflicting interests and goals, or different prioritizations among actors (Öberg and Shih 2014). Therefore, it is crucial for successful innovating to reach sufficient level of convergence in the logics among all actors that play important roles in the development and commercialization in the overall service ecosystem (Öberg and Shih 2014; Vargo et al. 2015).

Second, our analysis revealed challenges posed by competing and even conflicting institutional logics that that needed to be overcome for the $\mathrm{eRX}$ to gradually become institutionalized in the broader service ecosystem. These findings hence accentuate the importance of the question how convergent institutional logics in service ecosystems are created. Existing research on institutional logics suggest that actors resolve the contradictions in competing logics in two ways. Actors can retain the differences in logics, but learn to live with the difference it through collaboration (Reay and Hinings 2009) or stabilization of two co-existing logics as Ruef and Scott (1998) demonstrated in hospital reform context (medical-professional logic vs. administrative-managerial logic). In service ecosystems, this would mean that a group of actors representing a particular 'layer' or 'sub-system' to the broader whole would recognize the differences in competing logics, while still enabling coordination in the service ecosystem level. We found that visionaries and developers need to sufficiently understand the logics of end-users and key disseminators of innovation: in the eRX case, actors driving or managing the innovation somewhat failed to recognize and acknowledge different logics in the front part of the innovation process, but at the later part involved a larger set of actors in collaboration, thereby 
facilitating the deployment and diffusion of the innovation. Previous research provides also evidence of cases where institutional logics have been blended or reconfigured over time to new, shared logics among actors that previously held competing logics (e.g. Fuenfschilling and Truffer 2014). In the context of the eRX, one can argue that through increasing communication and engagement the key stakeholders over time converged towards to a partially shared view of the benefits and necessity of the eRX system despite maintaining some differing notions of its practical implementation, hence enabling the service ecosystem to function and create value in a better way (cf. Verleye et al., 2017).

The main contribution of this study to service science literature is to highlight the development and diffusion of major innovation as a process of institutionalization, analyzing in particular how competing institutional logics challenge this process in service ecosystems. This empirical illustration complements recent S-D logic based discussions on the role of institutions in innovation processes (e.g., Vargo et al. 2015, Koskela-Huotari et al. 2016; Wieland et al. 2015; Wallin and Fulgsang 2017). As Wallin and Fulgsang (2017) note, efforts for institutional change plays a crucial role in the service innovation process, but have not thus far received sufficient attention in service research. This study also demonstrated the importance of studying multiple layers of the service ecosystem (Figure 1) as together they host a range of stakeholders that gradually work towards or against institutionalizing the innovation. This notion contributes to innovation research that has typically focused on examining merely one layer at a time, such as end-users (e.g. Harrison and Waluszewski 2008) or technological infrastructures (Rohrbeck et al. 2009). In the studied case, successful adoption and diffusion of the service innovation was set back by overemphasizing the logic of technological effectiveness and the perspective of technological stakeholders. However, the success of the eRX was not only about deploying new information systems, but changing the everyday processes and norms of a range versatile actors, i.e. changing prevailing institutions. Failure in such caused years of delay in the studied innovation process. Our research brings new insights also into research on technological transformations by examining a service innovation context (Geels 2002).

Our case also shows that sometimes the innovation has the potential for providing benefits for a wide range of stakeholders but due to the extent of changes needed, as well as lack of vision or unclear short-term benefits, the majority of the key actors are unable or even unwilling to commit to the new regime, but a change agent from higher layers of the innovation ecosystem - a regulative body - needs to force the action. As ecosystems comprise interdependencies between actors, technologies and institutions (Aarikka-Stenroos and Ritala, 2017; Verleye et al., 2017), it is important to recognize which parts of the ecosystem need to actively facilitate the change and engage other actors along. Our research demonstrates that some stakeholders in the ecosystems are more equipped to facilitate the institutionalization process, pinpointing the need of effective network management (Aarikka-Stenroos et al. 2017). Walling and Fuglsang (2017) found that building legitimacy for the proposed innovation by mobilizing powerful players in the field is critical it enables 
modifications of institutional arrangements that protect the established health care regime. Similarly, our findings highlight the important role of supporting actors, such as policy makers and regulators, in influencing other actors in their decisions or abilities to pursue the innovation goal, and thereby facilitate the gradual convergence of logics in the service ecosystem.

The key managerial implication of this study is that innovating actors should focus not only on the process of product or service development and the immediate partners involved, but take into consideration the entire service ecosystem with versatile layers of stakeholders that may critically facilitate or hamper the institutionalization of the innovation in the long run. Mapping and understanding the institutional logics of such stakeholders and how they influence stakeholders' actions is needed to foresee potential barriers to the innovation diffusion. As the long term success of an innovation is determined by its ability to become institutionalized (cf. Vargo et al. 2015), facilitating the convergence of institutional logics of multiple ecosystem actors should begin at the very early stages of the innovation process.

As contemporary innovation environments often involves multiple stakeholders and extensive ecosystem contexts, the relevance of coping with and facilitating diversity in logics, priorities and goals is increasing. Thus, future research should examine how innovations are enabled, facilitated, and constrained in extensive service ecosystems, despite the methodological challenges originating from such diversity.

\section{References}

Aarikka-Stenroos, L., Jaakkola, E., Harrison, D. and Mäkitalo-Keinonen, T. (2017). How to manage innovation processes in extensive networks: A longitudinal study. Industrial Marketing Management, 67, 88-105.

Aarikka-Stenroos, L., Sandberg, B., \& Lehtimäki, T. (2014). Networks for the commercialization of innovations: A review of how divergent network actors contribute. Industrial Marketing Management, 43(3), 365-381.

Aarikka-Stenroos, L. \& Ritala, P. (2017). Network management in the era of ecosystems: Systematic review and management framework. Industrial Marketing Management, 67, 23-36.

Akaka, M. A., Vargo, S. L., \& Lusch, R. F. (2013). The complexity of context: A service ecosystems approach for international marketing. Journal of Marketing Research, 21(4), 1-20.

Association of Finnish Pharmacies (2016). Annual Review 2016. Available at http://www.apteekkariliitto.fi/en/association.html, retrieved in January 2018.

Capunzo, M., Polese, F., Boccia, G., Carrubbo, L., Clarizia, F., \& De Caro, F. (2013). Advances in service research for the understanding and the management of service in healthcare networks. In: Gummesson, E., Mele, C., Polese, F. (Eds.), Service Dominant Logic, Network and Systems Theory and Service Science: Integrating three Perspectives for a New Service Agenda, Giannini, Napoli.

D’Este, P., Iammarino, S., Savona, M., \& von Tunzelmann, N. (2012). What hampers innovation? Revealed barriers versus deterring barriers. Research Policy, 41, 2, 482-488.

Driessen, P. H., \& Hillebrand, B. (2013). Integrating multiple stakeholder issues in new product development: An exploration. Journal of Product Innovation Management, 30(2), 364-379. 
Edvardsson, B. \& Tronvoll, B. (2013). A new conceptualization of service innovation grounded in S-D logic and service systems. International Journal of Quality \& Service Sciences, 5(1), 19-31.

Edvardsson, B., Kleinaltenkamp, M., Tronvoll, B., McHugh, P., \& Windahl, C. (2014). Institutional logics matter when coordinating resource integration. Marketing Theory, 14(3), 291-309.

Eisingerich, A.B., Rubera, G. \& Seifert, M. (2009). Managing service innovation and interorganizational relationships for firm performance: To commit or diversify?, Journal of Service Research, 11(4), pp. 344-356

Flick, U. (2004). Triangulation in qualitative research. Companion to Qualitative Research. Ed. by U. Flick, E. von Kardorff \& I. Steinke. Sage: London, pp. 178-183.

Friedland, R., \& Alford, R. (1991). Bringing Society Back In: Symbols, Practices, and Institutional Contradictions. In. Powell, W. \& DiMaggio, P. (Eds.) The New Institutionalism in Organizational Analysis, University of Chicago Press.

Frow, P., McColl-Kennedy, J. R., \& Payne, A. (2016). Co-creation practices: Their role in shaping a health care ecosystem. Industrial Marketing Management, 56, 24-39.

Fuenfschilling, L., \& Truffer, B. (2014). The structuration of socio-technical regimes-Conceptual foundations from institutional theory. Research Policy, 43(4), 772-791.

Geels, F. W. (2002). Technological transitions as evolutionary reconfiguration processes: a multilevel perspective and a case-study. Research Policy, 31(8), 1257-1274.

Geels, F. W., \& Schot, J. (2007). Typology of sociotechnical transition pathways. Research Policy, 36(3), 399-417.

Halinen, A., \& Törnroos, J. A. (2005). Using case methods in the study of contemporary business networks. Journal of Business Research, 58(9), 1285-1297.

Harrison, D., \& Waluszewski, A. (2008). The development of a user network as a way to re-launch an unwanted product. Research Policy, 37(1), 115-130.

Häkkinen, U. (2005) The impact of changes in Finland's health care system. Health Economics, 14, S101-S118.

Koskela-Huotari, K., Edvardsson, B., Jonas, J.M., Sörhammar, D. and Witell, L., (2016). Innovation in service ecosystems-Breaking, making, and maintaining institutionalized rules of resource integration. Journal of Business Research, 69(8), 2964-2971.

Lawrence, T.B., \& Suddaby, R. (Eds.). (2006). Institutions and institutional work. London: Sage.

Litovuo, L., Makkonen, H., Aarikka-Stenroos, L., Luhtala, L., \& Makinen, S. (2017). Ecosystem approach on medical game development: the relevant actors, value propositions and innovation barriers. In: Proceedings of the 21 st International Academic Mindtrek Conference, ACM, 3544.

Maglio, P. P., \& Spohrer, J. (2008). Fundamentals of service science. Journal of the Academy of Marketing Science, 36(1), 18-20.

Markard, J., \& Truffer, B. (2006). Innovation processes in large technical systems: Market liberalization as a driver for radical change? Research Policy, 35(5): 609-625.

Markard, J., Wirth, S., \& Truffer, B. (2016). Institutional dynamics and technology legitimacy-A framework and a case study on biogas technology. Research Policy, 45(1), 330-344.

Ministry of Social Affairs and Health (2015). Information management in healthcare and social welfare. Available at: http://www.stm.fi/en/it-system-projects

Mohnen, P., \& Rosa, J.M. (2002). Barriers to innovation in service industries in Canada. In M.P. Feldman, \& N. Massard (Eds.), Institutions and Systems in the Geography of Innovation. Boston: Kluwer, 231-250.

Perks, H., Gruber, T., \& Edvardsson, B. (2012). Co-creation in radical service innovation: A systematic analysis of microlevel processes. Journal of Product Innovation Management, 29(6), $1-17$.

Reay, T., \& Hinings, C. R. (2009). Managing the rivalry of competing institutional logics. Organization Studies, 30(6), 629-652. 
Rohrbeck, R., Hölzle, K. \& Gemünden, H. G. (2009). Opening up for competitive advantage How Deutsche Telekom creates an open innovation ecosystem. $R \& D$ Management, 39(4): 420430.

Ruef, M., \& Scott, W. R. (1998). A Multidimensional Model of Organizational Legitimacy: Hospital Survival in Changing Institutional Environments. Administrative Science Quarterly, 43(4), 877-904.

Rusanen, H., Halinen, A., \& Jaakkola, E. (2014). Accessing resources for service innovation-the critical role of network relationships. Journal of Service Management, 25(1), 2-29.

Salmivalli, L. (2008) Governing the implementation of a complex inter-organizational information system network. Turku School of Economics, Tampere.

Samadbeik, M., Ahmadi, M., Sadoughi, F., \& Garavand, A. (2017). A copmarative review of electronic prescription systems: Lessons learned from developed countries. Journal of Research in Pharmacy Practice, 6(1), 3 .

Sandberg, B., \& Aarikka-Stenroos, L. (2014). What makes it so difficult? A systematic review on barriers to radical innovation. Industrial Marketing Management, 43(8), 1293-1305.

Scott, W. R. (1995) Institutions and organizations (2ed.). Sage Publications, thousand Oaks.

Spohrer, J. and Maglio, P.P. (2008). The emergence of service science: toward systematic service innovations to accelerate co-creation of value, Production and Operations Management, 17(3), 238-246.

Thornton, P. H., \& Ocasio, W. (1999). Institutional logics and the historical contingency of power in organizations: Executive succession in the higher education publishing industry, 1958-1990. American Journal of Sociology, 105(3), 801-843.

Thornton, P. H., and Ocasio, W. (2008). Institutional logics. The Sage handbook of organizational institutionalism, 840, 99-128.

Thornton, P. H., Ocasio, W., \& Lounsbury, M. (2012). The institutional logics perspective: A new approach to culture, structure, and process. Oxford University Press on Demand.

Troshani, I., \& Doolin, B. (2007). Innovation diffusion: a stakeholder and social network view. European Journal of Innovation Management, 10(2), 176-200.

Vaaland, T. I., \& Håkansson, H. (2003). Exploring interorganizational conflict in complex projects. Industrial Marketing Management, 32(2), 127-138

Vargo, S. L., Wieland, H., \& Akaka, M. A. (2015). Innovation through institutionalization: A service ecosystems perspective. Industrial Marketing Management, 44, 63-72.

Vargo, S. L., \& Lusch, R. F. (2015). Institutions and axioms: An extension and update of servicedominant logic. Journal of the Academy of Marketing Science, 1-9.

Wallin, A.J., \& Fuglsang, L. (2017). Service innovations breaking institutionalized rules of health care. Journal of Service Management, 28(5), pp.972-997.

Verleye, K., Jaakkola, E., Hodgkinson, I., Jun, G.T., Odekerken-Schröder, G. \& Quist, J. (2017). What causes imbalance in complex service networks? Evidence from a public health service. Journal of Service Management, 28(1), 34-56.

Wieland, H., Koskela-Huotari, K. and Vargo, S.L., 2016. Extending actor participation in value creation: an institutional view. Journal of Strategic Marketing, 24(3-4), pp.210-226.

Woodside, A. G., \& Biemans, W. G. (2005). Modeling innovation, manufacturing, diffusion and adoption/rejection processes. Journal of Business \& Industrial Marketing, 20(7), 380-393.

Zietsma, C., Groenewegen, P., Logue, D. M., \& Hinings, C. B. (2017). Field or fields? building the scaffolding for cumulation of research on institutional fields. Academy of Management Annals, 11(1), 391-450.

Öberg, C., and Shih, T. T. Y. (2014). Divergent and convergent logic of firms: Barriers and enablers for development and commercialization of innovations. Industrial Marketing Management, 43(3), 419-428. 


\section{Appendix 1. Case study methodology}

This study applies a single case strategy as it aims to investigate in detail an extensive, complex multi-actor case study on the development and dissemination of electronic prescription in Finland. Case studies are considered suitable for examining complex phenomena that are not easily separable from their context (Halinen and Törnroos 2005). In this study, the case consists of the development and diffusion process of the Finnish eRX within service ecosystems that comprise different kinds of actors that are engaging in, or affected by the innovation process.

The eRX case covers the time period of 2001-2016. Main sources of data for the case study comprise interviews, public report and studies, research publications, and media materials. Thematic interviews were conducted with a range of key stakeholders involved in the innovation process. The interviews revolved around their interests and goals with regard to the eRX, and perceptions on the critical events in the process. Due to the public nature and high societal relevance of the eRX project extensive media and open archive data on the case was available. The data comprise the following:

- $\quad 18$ interviews with key actors in the process, conducted in 2010, 2012, and 2016

- 9 sets of seminar presentation materials by different actors

- $\quad 3$ extensive, official pre-study and evaluation reports on the pilot studies

- $\quad>25$ publications in professional magazines, newspapers and websites

- 8 academic theses

By collecting different types of data along the development and commercialization process of electronic prescription and from different actors, we increased data triangulation (e.g. Flick 2004).

The analysis begun by developing an overview of the case by identifying the key actors involved and their activities in the innovation process. We also analysed what types of goals and perceptions each type of actors had with regard to the eRX. Next we identified the critical events along the years-long innovation process and sought for reasons for such event to have occurred, to form interpretations of the process of emerging convergence of institutional logics by the actors. 
Figure 1: Service ecosystem actors affecting the development and diffusion of eRX

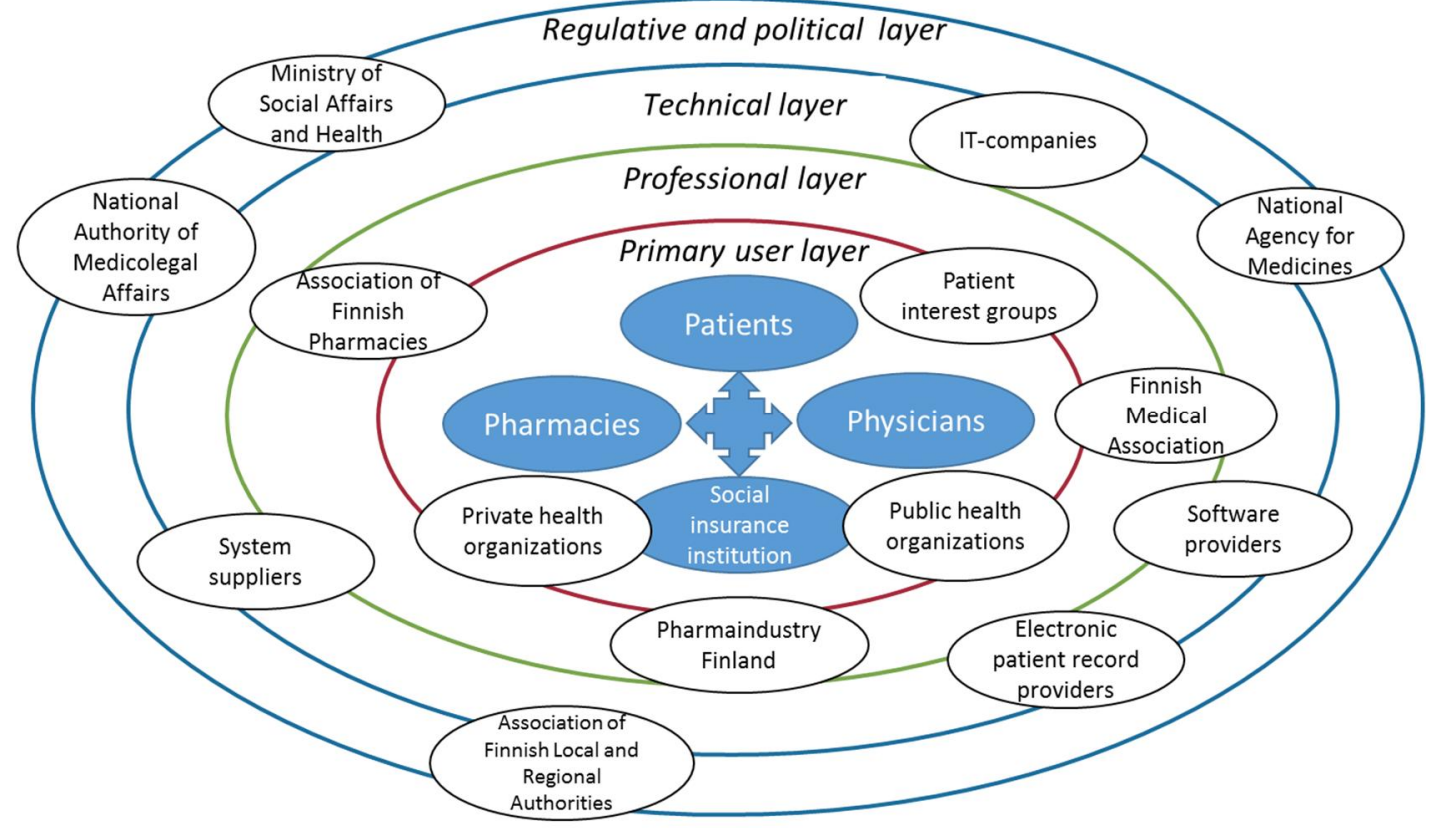

Figure 2. The process of eRX development and diffusion and key actors in each phase.

2001200220032004200520062007200820092010201120122013201420152016

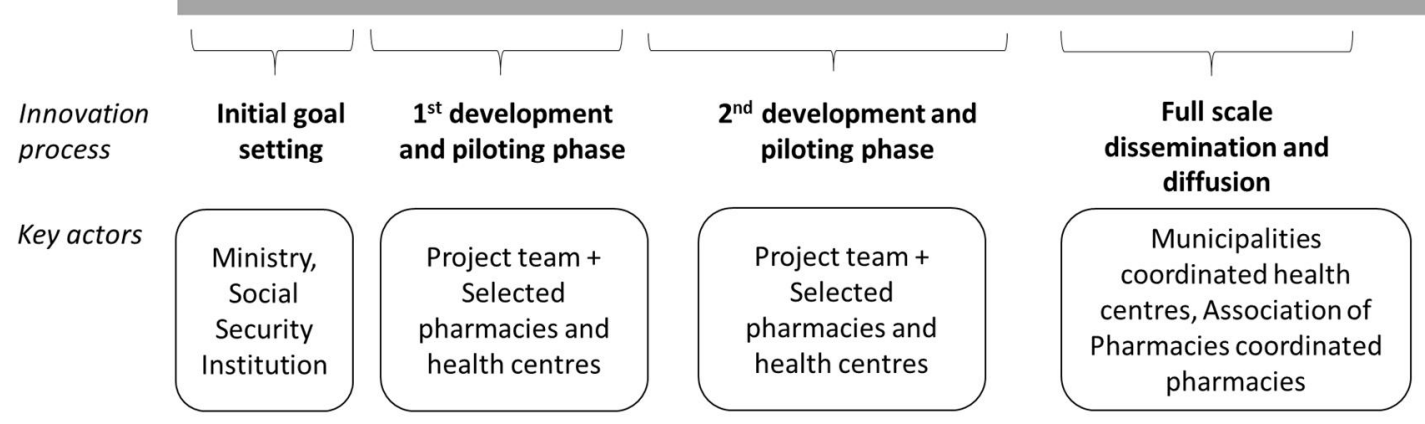


Table 1. Key events and challenges during the eRX development and diffusion process (see also Aarikka-Stenroos et al. 2017)

\begin{tabular}{|c|c|c|c|}
\hline $\begin{array}{l}\text { 2001-2002: Initial goal set- } \\
\text { ting }\end{array}$ & $\begin{array}{l}\text { 2003-2006: First development } \\
\text { and piloting phase }\end{array}$ & $\begin{array}{l}\text { 2007-2011: Second development } \\
\text { and piloting phase }\end{array}$ & $\begin{array}{l}\text { 2012-2015: Full scale dis- } \\
\text { semination and diffusion }\end{array}$ \\
\hline $\begin{array}{l}\text { - The Ministry wanted to see } \\
\text { Finland adopt eRX to im- } \\
\text { prove productivity and pa- } \\
\text { tient safety in health care } \\
\text { - The Ministry assigned SII } \\
\text { and NAM to explore the po- } \\
\text { tential for eRX } \\
\text { - Based on the report, the } \\
\text { Ministry made a decision for } \\
\text { developing the eRX }\end{array}$ & $\begin{array}{l}\text { - The Ministy started a project to } \\
\text { create the basic specification for } \\
\text { the system and invited four munic- } \\
\text { ipalities to take part in pilot pro- } \\
\text { jects } \\
\text { - The participating actors did not re- } \\
\text { ceive financial incentives and the } \\
\text { pilot projects were under-resourced } \\
\text { - The eRX plan affected a range of } \\
\text { diverse actors that each had their } \\
\text { own agenda and differing interests } \\
\text { - For pharmacies and health organi- } \\
\text { zations, there was no business } \\
\text { profit to motivate development } \\
\text { work } \\
\text { - The project was driven by individ- } \\
\text { uals who were personally moti- } \\
\text { vated and believed in the vision of } \\
\text { the Finnish eRX } \\
\text { - The piloting did not spread far } \\
\text { enough to show evidence on the } \\
\text { benefits of the system to different } \\
\text { stakeholders }\end{array}$ & $\begin{array}{l}\text { - The Ministry issued a law to oblige } \\
\text { the development of the eRX } \\
\text { - SII was given the operative lead of } \\
\text { the project } \\
\text { - Developing a fully functioning sys- } \\
\text { tem required resources of diverse ac- } \\
\text { tors } \\
\text { - Inertia and suspicion towards the } \\
\text { eRX system in pharmacies and } \\
\text { health centers } \\
\text { - Actors had conflicting interest as } \\
\text { municipalities had different IT- } \\
\text { infrastructures in use which made it } \\
\text { difficult to compromise } \\
\text { - Lack of holistic coordination of the } \\
\text { process as the Ministry was very far } \\
\text { from the practical work and other ac- } \\
\text { tors focused on their own agendas } \\
\text { - Participants were unsure about the } \\
\text { benefits of the system for them } \\
\text { - SII organized meetings with differ- } \\
\text { ent actor groups to commit them to } \\
\text { the eRX }\end{array}$ & $\begin{array}{l}\text { - Legislation imposed deadlines } \\
\text { for full implementation of } \\
\text { eRX } \\
\text { - Resentment in pharmacies and } \\
\text { health centers that lacked IT- } \\
\text { resources and disliked the im- } \\
\text { posing of a national system } \\
\text { - Deployment in health centers } \\
\text { and pharmacies was coordi- } \\
\text { nated by municipal hospital } \\
\text { districts and the Association of } \\
\text { Finnish Pharmacies } \\
\text { - SII organized seminars and } \\
\text { training sessions to promote } \\
\text { the eRX } \\
\text { - Nearly all pharmacies and } \\
\text { health centers had adopted } \\
\text { eRX by end of } 2014 \text {, showing } \\
\text { the convergence of logics } \\
\text { across actor groups }\end{array}$ \\
\hline
\end{tabular}

